\title{
Migraine, the menopause and hormone replacement therapy: a clinical review
}

\section{E Anne MacGregor}

\section{Overview}

In contrast to the relatively stable hormone profile during the middle reproductive years, the perimenopause is marked by erratic fluctuations of oestrogen and progesterone. By the late perimenopause, oestrogen levels can reach high magnitudes. ${ }^{1}$ Given the association between migraine and oestrogen 'withdrawal' it is not surprising that this stage of life is often accompanied by worsening migraine, which persists until oestrogen levels plateau post-menopause.

This paper reviews the effects that menopause and hormone replacement therapy (HRT) have on headache and migraine and considers the data on the risk of ischaemic stroke in HRT users with migraine. This evidence will be used to support practical guidance on the management of women with migraine wishing to use HRT.

\section{Search strategy}

A MEDLINE search from 1950 to April 2007 using the search terms 'headache', 'migraine', 'menopause', 'hormone replacement therapy', 'perimenopause', 'progestogen', 'progesterone', '(o)estrogen', '(o)estradiol' and 'selective (o)estrogen receptor modulators' identified 100 publications, which were scrutinised for relevancy to this review.

In addition, references from the author's own files, a hand-search of the journals Cephalalgia and Headache, and peer-reviewed presentations at international congresses were considered.

\section{Effect of the menopause on headache and migraine}

Headache is a common but under-reported complaint in perimenopausal women. A study of 74 women attending a London menopause clinic reported that in the preceding 3 months, 57\% had experienced headache and 29\% had experienced migraine. ${ }^{2}$ Migraine was associated with significant disability, with $80 \%$ of women affected reporting attacks more often than once a month, 75\% reporting severe attacks and 50\% reporting attacks lasting longer than 1 day.

In 1000 women attending a Leicester menopause clinic, $85 \%$ reported recurrent headache of which $73 \%$ reported headache more often than once a month. ${ }^{3}$ Migraine was reported by $24 \%$ of women.

In a retrospective questionnaire of 29 postmenopausal women with tension-type headache, six women (21\%) reported new onset of headache with menopause. ${ }^{4}$ Of those women who had had a physiological menopause, 27\% reported improvement or complete remission of headache following menopause, $13 \%$ reported no change and $60 \%$ reported worsening headache. Of those women who had had a surgical menopause, $38 \%$ reported improvement of

J Fam Plann Reprod Health Care 2007; 33(4): 245-249

(Accepted 30 July 2007)

The City of London Migraine Clinic, London, UK and Barts Sexual Health, St Bartholomew's Hospital, London, UK E Anne MacGregor, MFFP, Director of Clinical Research

Correspondence to: Dr Anne MacGregor, The City of London Migraine Clinic, 22 Charterhouse Square, London EC1M 6DX, UK. E-mail: anne.macgregor@sinoragram.co.uk headache following menopause, $38 \%$ reported no change and $25 \%$ reported worsening headache.

Studies support the clinical impression that migraine without aura improves post-menopause, with time since menopause being a significant factor. ${ }^{5}$ A study of 1436 women at various stages of the menopause reported a prevalence of migraine of $10.5 \%$ in postmenopausal women following natural menopause compared with a prevalence of $16.7 \%$ in premenopausal and perimenopausal women [odds ratio (OR) 0.6, 95\% CI $0.4-0.9, p=0.03] .{ }^{6}$ This improvement is generally attributed to the absence of variations in sex hormone levels. In accordance with this, ovarian failure, with low levels of oestrogen and high levels of follicle-stimulating hormone, is associated with a lower prevalence of migraine than in menstruating women. ${ }^{6}$ However, psychological factors also seem to play a fundamental role. ${ }^{4}$

There are few data regarding the effect of menopause on migraine with aura, although the clinical impression is one of little change.

Type of menopause is important, with a lower prevalence of migraine following physiological menopause compared to surgical menopause (Table 1). ${ }^{4,7}$ Regarding the type of surgical procedures resulting in menopause, the prevalence of migraine has been reported as lowest in those with hysterectomy and bilateral oophorectomy, although not to a statistically significant level (hysterectomy only, $28.6 \%$; hysterectomy with unilateral oophorectomy, $36.4 \%$; hysterectomy with bilateral oophorectomy, $15.8 \%$; $p=0.3) .^{6}$ There were no data on the effect of bilateral oophorectomy without hysterectomy. This study also suggested that self-reported premenstrual syndrome was associated with a greater adverse effect of surgical menopause on migraine prevalence and a greater beneficial effect of natural ovarian failure.

The effects of medical menopause on migraine can be attenuated by the addition of HRT. ${ }^{8}$

\section{Effect of HRT on headache}

There are few data on the association between headache and current use of HRT. A retrospective questionnaire of 120 women attending a headache clinic in the USA suggested that HRT was associated with improved outcome, with $64.1 \%$ of respondents reporting improvement or complete remission of headache, $22.5 \%$ reporting no change and $13.3 \%$ reporting worsening headache. ${ }^{9}$ In contrast, a cross-sectional questionnaire of 6007 postmenopausal women taking part in large Norwegian health survey (Nord-Trøndelag Health Study) showed a significant association between headache and current use of HRT. ${ }^{10}$ This was irrespective of whether the route of delivery was local (OR $1.3,95 \%$ CI 1.0-1.6) or systemic (OR 1.3, 95\% CI 1.1-1.5).

\section{Effect of HRT on migraine}

Questionnaire studies suggest a significant association between migraine and current use of HRT (Table 2).10,11 Some studies suggest that a history of worsening migraine at menopause is a factor in predicting worsening migraine with HRT. 3,9 However, it is not known whether HRT is associated with increased incidence of headache and migraine or whether HRT is initiated because of headache. 
Table 1 The effect of menopause on migraine

\begin{tabular}{|c|c|c|c|c|c|c|c|}
\hline \multirow[t]{2}{*}{ Study } & \multirow[t]{2}{*}{ Study design } & \multirow[t]{2}{*}{ Sample size } & \multicolumn{4}{|l|}{ Outcome } & \multirow[t]{2}{*}{ Significance } \\
\hline & & & $\begin{array}{l}\text { Improvement } \\
\text { or complete } \\
\text { remission }\end{array}$ & Unchanged & Worsened & $\begin{array}{l}\text { New } \\
\text { onset }\end{array}$ & \\
\hline \multirow[t]{3}{*}{$\begin{array}{l}\text { Neri et al. } \\
(1993)^{4}\end{array}$} & \multirow[t]{3}{*}{$\begin{array}{l}\text { Retrospective } \\
\text { questionnaire }\end{array}$} & $\begin{array}{l}47 \text { postmenopausal women } \\
\text { with migraine }\end{array}$ & $51 \%$ & $17 \%$ & $15 \%$ & $17 \%$ & \multirow[t]{3}{*}{$\begin{array}{l}{ }^{*} p=0.003 \\
\text { surgical vs } \\
\text { physiological }\end{array}$} \\
\hline & & Physiological menopause & $67 \%{ }^{*}$ & $24 \%$ & $9 \%$ & NR & \\
\hline & & Surgical menopause & $33 \%{ }^{*}$ & $0 \%$ & $67 \%$ & NR & \\
\hline \multirow{2}{*}{$\begin{array}{l}\text { Granella et al. } \\
(1993)^{7}\end{array}$} & \multirow{2}{*}{$\begin{array}{l}\text { Retrospective } \\
\text { observational } \\
\text { study }\end{array}$} & 116 physiological menopause & $24.1 \% *$ & $43.1 \%$ & $27.6 \%{ }^{* *}$ & $5.2 \%$ & ${ }^{*} p<0.01$ \\
\hline & & 48 surgical menopause & $0 \% *$ & $50 \%$ & $37.5 \%{ }^{* *}$ & $12.5 \%$ & ${ }^{* *} p<0.02$ \\
\hline $\begin{array}{l}\text { Mueller } \\
(2000)^{9}\end{array}$ & $\begin{array}{l}\text { Retrospective } \\
\text { questionnaire }\end{array}$ & 168 postmenopausal women & $24.4 \%$ & $39.8 \%$ & $35.7 \%$ & NR & NR \\
\hline \multirow[t]{2}{*}{$\begin{array}{l}\text { Martin et al. } \\
(2003)^{8}\end{array}$} & \multirow[t]{2}{*}{$\begin{array}{l}\text { Randomised } \\
\text { placebo- } \\
\text { controlled } \\
\text { study }\end{array}$} & $\begin{array}{l}9 \text { medical menopause with } \\
1 \text { month goserilin followed by } \\
2 \text { months goserilin + add-back } \\
\text { oestradiol }\end{array}$ & $\begin{array}{l}37 \% \text { reduction } \\
\text { in headache } \\
\text { index during } \\
\text { oestradiol } \\
\text { treatment }\end{array}$ & \multirow[t]{2}{*}{ NR } & & \multirow[t]{2}{*}{ NR } & \multirow[t]{2}{*}{$p=0.025$} \\
\hline & & $\begin{array}{l}12 \text { medical menopause with } \\
1 \text { month goserilin followed by } \\
2 \text { months goserilin + placebo }\end{array}$ & No change & & & & \\
\hline
\end{tabular}

NR, not reported.

\section{Oestrogen}

\section{Regimen}

Oestrogen replacement should be given continuously as oestrogen 'withdrawal' migraine can occur, in addition to return of menopause symptoms, with cyclical regimens. ${ }^{12}$

\section{Type of oestrogen}

There are no data on the differential effects of human or equine oestrogens on migraine.

\section{Route of delivery}

Non-oral routes are less likely to have a detrimental effect on migraine than oral formulations of oestrogen replacement (Table 3). ${ }^{13,14}$ This is probably the result of the more stable serum hormone levels associated with nonoral routes. ${ }^{15}$ If oral preparations are favoured, tibolone may be the preferred option. ${ }^{16}$

\section{Dose}

Oestrogen replacement therapy can have an adverse effect on migraine aura as evidenced by a report of 10 women seen in an ophthalmology clinic who were using transdermal oestrogen patches $50 \mu \mathrm{g}$ daily, of whom six had a history of migraine (three migraine with aura, three migraine without aura) before using replacement therapy. ${ }^{17}$ All six women developed increased headache severity and accompanying visual scintillations. One patient with no previous history of migraine developed visual scintillations with no accompanying headache. Withdrawal of oestrogens and additional prophylactic antimigraine therapy led to marked improvement in all women, with complete cessation of migraine in four patients.

However, complete withdrawal of HRT may be unnecessary, as case reports on four women developing migraine aura following initiation of HRT showed that, in all cases, aura resolved with either a reduction in oestrogen dose or change in route of delivery of oestrogen. ${ }^{18}$

\section{Progestogen}

Regimen

Continuous combined HRT appears to be better tolerated by migraineurs than cyclical combined HRT. ${ }^{19}$

Type, route of delivery and dose of progestogen

There are no data regarding the effect on migraine of different types, routes of delivery or doses of progestogens used for HRT. However, progestogen intolerance resulting in bleeding problems, fluid retention, headache and negative mood adversely affects compliance. ${ }^{20}$

Table 2 The effect of hormone replacement therapy on migraine: users versus never-users

\begin{tabular}{lllll}
\hline Study & Study design & Sample size & OR & Comments \\
\hline $\begin{array}{l}\text { Misakian } \text { et al. } \\
(2003)^{11}\end{array}$ & $\begin{array}{l}\text { Population-based } \\
\text { questionnaire }\end{array}$ & $\begin{array}{l}\text { Women's Health Study of 21 788 } \\
\text { postmenopausal women of whom 17 107 } \\
\text { were perimenopausal at baseline and who } \\
\text { were never (38.5\%) or current (61.5\%) } \\
\text { users of HRT }\end{array}$ & $\begin{array}{l}1.42(95 \% \mathrm{Cl} \text { (1.24-1.62) } \\
\text { Aegidius } \text { et al. }\end{array}$ & $\begin{array}{l}\text { ORs were similar for oestrogen- } \\
\text { only and combined oestrogen- } \\
\text { progestogen HRT }\end{array}$ \\
$\begin{array}{l}\text { Cross-sectional } \\
\text { questionnaire }\end{array}$ & $\begin{array}{l}\text { Nord-Trøndelag Health Study of 29 679 } \\
\text { women of whom 18 323 had headache } \\
\text { and 2375 used or had used HRT }\end{array}$ & $\begin{array}{l}1.6(95 \% \mathrm{Cl} \\
1.4-1.9)\end{array}$ & $\begin{array}{l}\text { Oestrogen-only OR 1.7 (95\% Cl } \\
1.4-2.0) ; \text { combined oestrogen- } \\
\text { progestogen OR 1.7 (95\% Cl } \\
1.2-2.4)\end{array}$ \\
\hline
\end{tabular}

HRT, hormone replacement therapy; OR, odds ratio. 
Table 3 The effect of different types of hormone replacement therapy on episodic tension-type headache and migraine

\begin{tabular}{|c|c|c|c|c|}
\hline Study & Study design & Comparator drugs & Effect on ETTH & Effect on migraine \\
\hline \multirow[t]{2}{*}{$\begin{array}{l}\text { Nappi et al. } \\
(2001)^{14}\end{array}$} & \multirow{2}{*}{$\begin{array}{l}\text { RCT of transdermal cyclical } \\
\text { combined HRT vs oral } \\
\text { cyclical combined HRT over } \\
6 \text { months in } 30 \text { women with } \\
\text { migraine without aura and } \\
20 \text { women with ETTH }\end{array}$} & $\begin{array}{l}50 \mu \mathrm{g} \text { transdermal oestradiol } \\
\text { patches daily plus } 10 \mathrm{mg} \\
\text { MPA on Days } 15-28\end{array}$ & No change & No change \\
\hline & & $\begin{array}{l}0.625 \mathrm{mg} \text { CEE daily plus } \\
10 \mathrm{mg} \text { MPA on Days } 15-28\end{array}$ & No change & $\begin{array}{l}\text { Increased frequency of attacks } \\
(p<0.0001) \\
\text { Increased number of days with } \\
\text { headache ( } p<0.0001) \\
\text { Increased use of analgesics } \\
(p=0.001)\end{array}$ \\
\hline \multirow[t]{3}{*}{$\begin{array}{l}\text { Facchinetti } \\
\text { et al. } \\
(2002)^{19}\end{array}$} & \multirow{3}{*}{$\begin{array}{l}\text { RCT of oral continuous } \\
\text { combined HRT vs oral } \\
\text { cyclical combined HRT vs } \\
\text { oral sequential cyclical HRT } \\
\text { over } 6 \text { months in } 38 \text { women } \\
\text { with migraine }\end{array}$} & $\begin{array}{l}1 \mathrm{mg} \text { oestradiol hemihydrate } \\
\text { plus } 0.5 \mathrm{mg} \mathrm{NET} \text { daily }\end{array}$ & \multirow[t]{3}{*}{ Not applicable } & $\begin{array}{l}\text { Compared to baseline, treatment } \\
\text { was associated in all three } \\
\text { subqroups with increase in attack }\end{array}$ \\
\hline & & $\begin{array}{l}0.625 \text { mg CEE daily plus } \\
10 \text { mg MPA on Days 15-28 }\end{array}$ & & $\begin{array}{l}\text { frequency }(p<0.001) \text {, severity } \\
(p<0.001) \text {, days with headache } \\
(p<0.001) \text { and analgesic }\end{array}$ \\
\hline & & $\begin{array}{l}2 \mathrm{mg} \text { oestradiol valerate } \\
\text { daily for } 21 / 28 \text { days plus } \\
1 \mathrm{mg} \text { cyproterone acetate } \\
\text { on Days } 12-21\end{array}$ & & $\begin{array}{l}\text { consumption }(p<0.001) \text { although } \\
\text { attacks were shorter }(p=0.005) \\
\text { Continuous combined regimen } \\
\text { was better tolerated than cyclical } \\
\text { and sequential regimens }\end{array}$ \\
\hline \multirow[t]{2}{*}{$\begin{array}{l}\text { Nappi et al. } \\
(2006)^{16}\end{array}$} & \multirow[t]{2}{*}{$\begin{array}{l}\text { RCT of low-dose oral } \\
\text { continuous combined HRT } \\
\text { vs oral tibolone over } \\
6 \text { months in } 40 \text { women } \\
\text { with migraine without } \\
\text { aura or ETTH }\end{array}$} & $\begin{array}{l}1 \mathrm{mg} \text { 17-beta-oestradiol } \\
\text { plus } 0.5 \mathrm{mg} \text { NET daily }\end{array}$ & $\begin{array}{l}\text { Reduced number of days } \\
\text { with headache }(p<0.005) \\
\text { Reduced severity }(p<0.01) \\
\text { Reduced analgesic } \\
\text { consumption }(p<0.001)\end{array}$ & $\begin{array}{l}\text { Increased number of days with } \\
\text { migraine headache }(p<0.001) \\
\text { Increased number of analgesics } \\
(p<0.001)\end{array}$ \\
\hline & & $2.5 \mathrm{mg}$ tibolone daily & $\begin{array}{l}\text { Reduced number of days } \\
\text { with headache }(p<0.001) \\
\text { Reduced severity }(p<0.001) \\
\text { Reduced analgesic } \\
\text { consumption }(p<0.002)\end{array}$ & $\begin{array}{l}\text { No effect on number of days with } \\
\text { migraine headache } \\
\text { Reduced severity }(p<0.001) \\
\text { Reduced number of analgesics } \\
(p<0.001)\end{array}$ \\
\hline
\end{tabular}

CEE, conjugated equine oestrogens; ETTH, episodic tension-type headache; HRT, hormone replacement therapy; MPA, medroxyprogesterone acetate; NET, norethisterone acetate; RCT, randomised controlled trial.

\section{Risk of cardiovascular disease in women with migraine}

Migraine with aura is a risk factor for ischaemic stroke. ${ }^{21-30}$ Most of these studies assessed young women with ischaemic stroke and there are few data on older populations. More recent studies suggest that migraine with aura is also a risk factor for cardiovascular disease.

Analysis of 5125 women aged over 45 years participating in the prospective cohort Women's Health Study showed that only active migraine with aura at baseline, and not a past history, was a risk factor for ischaemic stroke, myocardial infarction, angina and death due to ischaemic cardiovascular disease. This association with ischaemic stroke was significantly modified by age ( $p$ $=0.01)$ with the highest association among women younger than 50 years [hazard ratio (HR) $6.16,95 \% \mathrm{CI}$ 2.34-16.21].30 In contrast, the association between active migraine with aura and myocardial infarction was not significantly modified by age and remained elevated among women aged 60 years or older (HR 1.95, 95\% CI 0.91-4.19).

A population-based study in The Netherlands compared the cardiovascular risk profile of migraineurs to that of non-migraineurs aged 20 to 65 years. A total of 620 current migraineurs were compared to 5135 individuals without lifetime migraine. Migraineurs with aura were more likely to report a history of early-onset coronary heart disease or stroke (OR 3.96, 95\% CI 1.1-14.3).28

Migraine may be associated with a higher prevalence of hypertension, elevated cholesterol, abnormalities of haemostasis and patent foramen ovale. ${ }^{28,30-33}$ The risk associated with migraine is independent of these factors as it remains increased even when the analyses control for other major stroke risk factors. ${ }^{28,30}$

\section{Risk of cardiovascular disease in women using HRT}

Concerns regarding an increased risk of cardiovascular disease associated with use of HRT are unjustified as they relate to an atypical population of postmenopausal women starting HRT. ${ }^{34}$ There is evidence from controlled trials to support earlier observations that HRT initiated during the perimenopause is not associated with increased risk of stroke and cardiovascular disease and is more likely to have beneficial effects. ${ }^{35-37}$

On this basis there are theoretical benefits for women with migraine wishing to start HRT in the perimenopause. However, there are no data on risk of cardiovascular disease associated with new onset of migraine aura in women using HRT.

\section{Risk of cardiovascular disease in women with migraine using HRT}

There are few studies assessing the risk of ischaemic stroke or myocardial infarction in women with migraine using HRT. The Women's Health Study did not find an association between these conditions and use of postmenopausal hormone therapy in women with migraine with or without aura. ${ }^{30}$

\section{Alternatives to HRT}

Reviews and recommendations for effective alternatives to HRT in women with vasomotor symptoms support the use of fluoxetine, paroxetine, venlafaxine or gabapentin. ${ }^{38,39}$

Evidence of efficacy for migraine prophylaxis has been shown for fluoxetine and venlafaxine.40-43 Initial exacerbation of migraine in the first few weeks of treatment is an effect of some selective serotonin reuptake inhibitors (SSRIs) so it is important not to stop treatment 
too early. ${ }^{44}$ Gabapentin can also be used for migraine prophylaxis, although evidence of efficacy is far from robust. .5 The most common adverse events reported are dizziness and sedation.

The efficacy and safety of complementary therapies have not been demonstrated, although phyto-oestrogens are widely used for vasomotor symptom control. One randomised controlled trial suggests some efficacy in menstrual migraine but, conversely, there is one case report of new-onset migraine following initiation of isoflavone supplements. 46,47

There are no data on the effect of selective oestrogen receptor modulators (SERMS) on postmenopausal women with migraine, although prescription-event monitoring has been used to assess safety in 13987 patients for whom useful information was available. ${ }^{48}$ Flushing was the most common specific adverse event reported. Headache/ migraine was the third most frequently reported adverse drug reaction associated with starting raloxifene and the fifth most frequently reported reason for stopping the drug. Although these data are limited, they do not support the use of SERMS as an alternative to HRT in women with migraine.

\section{Practical recommendations for use of HRT (Box 1)}

Headache in perimenopausal women is most likely to be a reflection of the background prevalence of migraine in the different age groups. ${ }^{49}$ Prospective data do not support an association between migraine with or without aura and ischaemic stroke in postmenopausal women, but do support an association between migraine with aura and increased risk of ischaemic stroke and myocardial infarction. Given the association between aura and cardiovascular risk factors, it is important to evaluate these risk factors and treat them appropriately.

There is no evidence that the treatment of menopausal symptoms in women with migraine should differ from standard recommendations, including use of HRT. There are theoretical and clinical benefits to non-oral oestrogen replacement for all women wishing to use HRT. ${ }^{50}$ For women with migraine, the evidence suggests that low-dose non-oral preparations of oestradiol should be recommended as first choice. Continuous progestogens are better tolerated than cyclical progestogens. Changing the type of progestogen can help, as side effects are fewer with progesterone derivatives such as medroxyprogesterone acetate and dydrogesterone than with testosterone derivatives such as norethisterone. ${ }^{20}$ Drospirenone is a more recent well-tolerated option although it is currently only available as an oral preparation combined with oestrogen. ${ }^{51}$ Changing route from oral to transdermal progestogen may also be effective, as may reducing the course of cyclical progestogens to only 7-10 days per month, although the latter is potentially associated with increased risk of endometrial hyperplasia. Natural progesterone is available as suppositories, micronised tablets and vaginal gel, although the availability of these different formulations varies worldwide. Sedation is a common adverse effect of natural progesterone. A welltolerated option is the levonorgestrel-releasing intrauterine system used with oestrogen supplementation. ${ }^{52}$ Occasionally progestogenic adverse effects are sufficiently bothersome for a woman to choose to discontinue progestogens. In these cases specialist referral is appropriate for regular endometrial assessment.

Although migraine attacks may increase when HRT is initiated, there is usually improvement with continued use. Any new-onset headache should be carefully evaluated for secondary causes, as although migraine may occasionally
Box 1: Optimising hormone replacement therapy (HRT) for women with migraine

- Migraine aura is not a contraindication to use of HRT.

- If aura appears for the first time after starting HRT, reduce the dose of oestrogen and consider changing route of delivery (oral to patch, patch to gel).

- Use the lowest effective dose of non-oral oestrogens that will control vasomotor symptoms.

- Where progestogen is required, continuous delivery is best, with preparations such as:

- levonorgestrel intrauterine system

progesterone-derived progestogens (e.g. dydrogesterone) rather than testosterone derivatives (e.g. norethisterone) drospirenone

micronised progesterone, or progesterone suppositories or vaginal gel, if available.

- If progestogens are not tolerated, consider discontinuation but with regular endometrial assessment.

develop for the first time during the perimenopause, it is unusual for migraine to begin post-menopause. ${ }^{53}$

There are no data regarding risk associated with developing a first attack of migraine with aura when using HRT. There is the concern that transient ischaemic attacks (TIAs) may be misdiagnosed as aura since it is not always easy to distinguish between the two conditions. ${ }^{54}$ On a practical basis, once TIAs have been excluded, the dose and route of delivery of oestrogen replacement should be assessed to provide the lowest effective dose necessary to control menopause symptoms.

For symptomatic and prophylactic treatment of migraine standard strategies apply. ${ }^{55}$ Given the association between migraine aura and increased risk factors for cardiovascular disease, these should be assessed and managed accordingly. Unless the woman's cardiovascular risk profile contraindicates triptans, there is no evidence that triptan use is associated with increased risk of stroke or cardiovascular disease. ${ }^{56}$

\section{Conclusions}

Headache and migraine are common symptoms of the menopause but are often under-reported. Perimenopausal women should routinely be asked about headache and migraine so that they can be offered appropriate advice. This should include optimal symptomatic treatment for attacks and strategies for prevention. In women with additional menopause symptoms, management may include use of continuous HRT via a non-oral route, using the lowest effective dose necessary to control symptoms.

\section{Statements on funding and competing interests}

Funding None identified.

Competing interests None identified.

References

1 Miro F, Parker SW, Aspinall LJ, Coley J, Perry PW, Ellis JE. Sequential classification of endocrine stages during reproductive aging in women: the FREEDOM study. Menopause 2005: 12: 281-290.

2 MacGregor EA, Barnes D. Migraine in a specialist menopause clinic. Climacteric 1999; 2: 218-223.

3 Hodson J, Thompson J, al-Azzawi F. Headache at menopause and in hormone replacement therapy users. Climacteric 2000; 3: 119-124.

4 Neri I, Granella F, Nappi R, Manzoni GC, Facchinetti F, Genazzani AR. Characteristics of headache at menopause: a clinico-epidemiologic study. Maturitas 1993; 17: 31-37.

5 Mattsson P. Hormonal factors in migraine: a population-based study of women aged 40 to 74 years. Headache 2003; 43: $27-35$

6 Wang SJ, Fuh JL, Lu SR, Juang KD, Wang PH. Migraine prevalence during menopausal transition. Headache 2003; 43: 470-478. 
7 Granella F, Sances G, Zanferrari C, Costa A, Martignoni E, Manzoni GC. Migraine without aura and reproductive life events: a clinical epidemiological study in 1300 women. Headache 1993; 33: 385-389.

8 Martin V, Wernke S, Mandell K, Zoma W, Bean J, Pinney S, et al. Medical oophorectomy with and without estrogen add-back therapy in the prevention of migraine headache. Headache 2003; 43: 309-321.

9 Mueller L. Predictability of exogenous hormone effect on subgroups of migraineurs. Headache 2000; 40: 189-193.

10 Aegidius KL, Zwart JA, Hagen K, Schei B, Stovner LJ. Hormone replacement therapy and headache prevalence in postmenopausal women. The Head-HUNT study. Eur J Neurol 2007; 14: 73-78.

11 Misakian AL, Langer RD, Bensenor IM, Cook NR, Manson JE, Buring JE, et al. Postmenopausal hormone therapy and migraine headache. J Womens Health (Larchmt) 2003; 12: $1027-1036$

12 Kudrow $L$. The relationship of headache frequency to hormone use in migraine. Headache 1975; 15: 36-40.

13 MacGregor A. Effects of oral and transdermal estrogen replacement on migraine. Cephalalgia 1999; 19: 124-125.

14 Nappi RE, Cagnacci A, Granella F, Piccinini F, Polatti F, Facchinetti $F$. Course of primary headaches during hormone replacement therapy. Maturitas 2001; 38: 157-163.

$15 \mathrm{Kuhl} \mathrm{H}$. Pharmacokinetics of oestrogen and progestogens. Maturitas 1990; 12: 171-197.

16 Nappi RE, Sances G, Sommacal A, Detaddei S, Facchinetti F, Cristina S, et al. Different effects of tibolone and low-dose EPT in the management of postmenopausal women with primary headaches. Menopause 2006; 13: 818-825.

17 Kaiser HJ, Meienberg O. Deterioration of onset of migraine under oestrogen replacement therapy in the menopause. J Neurol Neurosurg Psychiatr 1993; 240: 195-197.

18 MacGregor A. Estrogen replacement and migraine aura. Headache 1999; 39: 674-678.

19 Facchinetti F, Nappi RE, Tirelli A, Polatti F, Nappi G, Sances G. Hormone supplementation differently affects migraine in postmenopausal women. Headache 2002; 42: 924-929.

20 Panay N, Studd J. Progestogen intolerance and compliance with hormone replacement therapy in menopausal women. Hum Reprod Update 1997; 3: 159-171.

21 Henrich JB, Horwitz LA. A controlled study of ischemic stroke risk in migraine patients. J Clin Epidemiol 1989; 42: 773-780.

22 Tzourio C, Iglesias S, Hubert JB, Visy JM, Alperovitch A, Tehindrazanarivelo $\mathrm{A}$, et al. Migraine and risk of ischaemic stroke: a case-control study. BMJ 1993; 307: 289-292.

23 Tzourio C, Tehindrazanarivelo A, Iglesias S, Alperovitch A, Chedru F, d'Anglejan-Chatillon J, et al. Case-control study of migraine and risk of ischaemic stroke in young women. $B M J$ 1995; 310: 830-833.

24 Carolei A, Marini C, De Matteis G. History of migraine and risk of cerebral ischaemia in young adults. The Italian National Research Council Study Group on Stroke in the Young. Lancet 1996; 347: 1503-1506.

25 Chang C, Donaghy M, Poulter N, and World Health Organisation Collaboration Study of Cardiovascular Disease and Steroid Hormone Contraception. Migraine and stroke in young women: case-control study. BMJ 1999; 318: 13-18.

26 Nightingale AL, Farmer RD. Ischemic stroke in young women: a nested case-control study using the UK General Practice Research Database. Stroke 2004; 35: 1574-1578.

27 Kurth T, Slomke MA, Kase CS, Cook NR, Lee IM, Gaziano JM, et al. Migraine, headache, and the risk of stroke in women: a prospective study. Neurology 2005; 64: 1020-1026.

28 Scher Al, Terwindt GM, Picavet HS, Verschuren WM, Ferrari MD, Launer LJ. Cardiovascular risk factors and migraine: the GEM population-based study. Neurology 2005; 64: 614-620.

29 Stang PE, Carson AP, Rose KM, Mo J, Ephross SA, Shahar E, et al. Headache, cerebrovascular symptoms, and stroke: the Atherosclerosis Risk in Communities Study. Neurology 2005; 64: 1573-1577.

30 Kurth T, Gaziano JM, Cook NR, Logroscino G, Diener H-C, Buring JE. Migraine and risk of cardiovascular disease in women. JAMA 2006; 296: 283-291.

31 Crassard I, Conard J, Bousser MG. Migraine and haemostasis. Cephalalgia 2001; 21: 630-636.

32 Schwerzmann $M$, Nedeltchev $K$, Lagger F, Mattle HP, Windecker S, Meier B, et al. Prevalence and size of directly detected patent foramen ovale in migraine with aura. Neurology 2005; 65: 1415-1418.

33 Anzola GP, Magoni M, Guindani M, Rozzini L, Dalla Volta G. Potential source of cerebral embolism in migraine with aura: a transcranial Doppler study. Neurology 1999; 52: 1622-1625.
34 Wassertheil-Smoller S, Hendrix SL, Limacher M, Heiss G, Kooperberg C, Baird A, et al; WHI Investigators. Effect of estrogen plus progestin on stroke in postmenopausal women: the Women's Health Initiative: a randomized trial. JAMA 2003; 289: 2673-2684.

35 Li C, Engstrom G, Hedblad B, Berglund G, Janzon L. Risk of stroke and hormone replacement therapy: a prospective cohort study. Maturitas 2005: 54: 11-18.

36 Rosano GMC, Vitale C, Fini M. Hormone replacement therapy and cardioprotection: what is good and what is bad for the cardiovascular system? Ann NY Acad Sci 2006; 1092: 341-348.

37 Rossouw JE, Prentice RL, Manson JE, Wu L, Barad D, Barnabei VM, et al. Postmenopausal hormone therapy and risk of cardiovascular disease by age and years since menopause. JAMA 2007; 297: 1465-1477.

38 Board of the International Menopause Society, Pines A, Sturdee DW, Birkhauser MH, Schneider HP, Gambacciani M, Panay N. IMS updated recommendations on postmenopausal hormone therapy. Climacteric 2007; 10: 181-194.

39 Treatment of menopause-associated vasomotor symptoms: position statement of The North American Menopause Society. Menopause 2004; 11: 11-33.

40 Steiner TJ, Ahmed F, Findley LJ, MacGregor EA, Wilkinson M. S-Fluoxetine in the prophylaxis of migraine: a phase II doubleblind randomized placebo-controlled study. Cephalalgia 1998; 18: 283-286.

41 d'Amato CC, Pizza V, Marmolo T, Giordano E, Alfano V, Nasta A. Fluoxetine for migraine prophylaxis: a double-blind trial. Headache 1999; 39: 716-719.

42 Ozyalcin SN, Talu GK, Kiziltan E, Yucel B, Ertas M, Disci R. The efficacy and safety of venlafaxine in the prophylaxis of migraine. Headache 2005; 45: 144-152.

43 Bulut S, Berilgen MS, Baran A, Tekatas A, Atmaca M, Mungen B. Venlafaxine versus amitriptyline in the prophylactic treatment of migraine: randomized, double-blind, crossover study. Clin Neurol Neurosurg 2004; 107: 44-48.

44 Bickel A, Kornhuber J, Maihofner C, Ropohl A. Exacerbation of migraine attacks during treatment with the selective serotonin reuptake inhibitor sertraline. A case report. Pharmacopsychiatry 2005; 38: 327-328.

45 Mathew NT, Rapoport A, Saper J, Magnus L, Klapper J, Ramadan $\mathrm{N}$, et al. Efficacy of gabapentin in migraine prophylaxis. Headache 2001; 41: 119-128.

46 Burke BE, Olson RD, Cusack BJ. Randomized, controlled trial of phytoestrogen in the prophylactic treatment of menstrual migraine. Biomed Pharmacother 2002; 56: 283-288.

47 Engel PA. New onset migraine associated with use of soy isoflavone supplements. Neurology 2002; 59: 1289-1290.

48 Layton D, Clarke A, Wilton LV, Shakir SA. Safety profile of raloxifene as used in general practice in England: results of a prescription-event monitoring study. Osteoporos Int 2005; 16: 490-500.

49 Steiner TJ, Scher Al, Stewart WF, Kolodner K, Liberman J, Lipton RB. The prevalence and disability burden of adult migraine in England and their relationships to age, gender and ethnicity. Cephalalgia 2003; 23: 519-527.

50 Ho JY, Chen MJ, Sheu WH, Yi YC, Tsai AC, Guu HF, et al. Differential effects of oral conjugated equine estrogen and transdermal estrogen on atherosclerotic vascular disease risk markers and endothelial function in healthy postmenopausal women. Hum Reprod 2006; 21: 2715-2720.

51 White WB, Hanes V, Chauhan V, Pitt B. Effects of a new hormone therapy, drospirenone and 17-beta-estradiol, in postmenopausal women with hypertension. Hypertension 2006; 48: 246-253.

52 Hampton NR, Rees MC, Lowe DG, Rauramo I, Barlow D, Guillebaud J. Levonorgestrel intrauterine system (LNG-IUS) with conjugated oral equine estrogen: a successful regimen for HRT in perimenopausal women. Hum Reprod 2005; 20 : 2653-2660.

53 Cull RE. Investigation of late-onset migraine. Scot Med J 1995; 40: $50-52$

54 Bousser MG, Conard J. TIAs, migraine and platelets. Headache 1987; 27: 522 .

55 Steiner TJ, MacGregor EA, Davies PTG. Guidelines for All Healthcare Professionals in the Diagnosis and Management of Migraine, Tension-Type, Cluster and Medication-Overuse Headache (3rd edn). 2007. http://216.25.100.131/upload/ NS_BASH/BASH_guidelines_2007.pdf [Accessed 10 June 2007]

56 Hall GC, Brown MM, Mo J, MacRae KD. Triptans in migraine: the risks of stroke, cardiovascular disease, and death in practice. Neurology 2004; 62: 563-568. 